\title{
Recent Landslide Damming Events and Their Hazard Mitigation Strategies
}

\author{
Ahsan Sattar and Kazuo Konagai \\ Institute of Industrial Science, University of Tokyo \\ Japan
}

\section{Introduction}

Earthquakes often strike the vulnerable parts of our society. A 7.0-magnitude earthquake shattered Port-au-Prince, the capital of Haiti. Based on historical records in the Port-auPrince area, the last large earthquake happened in 1770. Therefore, throughout its history, the capital of the country had never experienced any deadly earthquake, but long-lasting political violence. Being the poorest country in the Americas as per the Human Development Index, due attention has never been paid to seismic preparedness, causing the catastrophic devastation with 316,000 casualties to occur (Reuters, 12 January 2010). Even in Japan with advanced technologies in disaster preparedness, the earthquake and tsunami of March 11th 2011 revealed vulnerabilities of disaster prevention schemes/ systems given the tsunami heights exceeding the determined design heights. These devastations often cause long lasting problems. In Haiti 2 million people are managing to get by on food rations. In Japan, huge amount of tsunami debris are just piled up in temporary damp yards with the fear that they might have been radiation-contaminated, thus discouraging all attempts for quick rehabilitations.

One of the most serious and costliest post earthquake problems is the stabilization of earthquake-induced landslide and debris masses. Shaking from the January 12, 2010, Haiti earthquake caused devastating structural damage and triggered many landslides that blocked roads, dammed rivers and streams, and threatened infrastructure in many parts of Haiti. About 4000 to 5000 landslides were estimated by the USGS (Randall at el., 2011). Many of the landslides blocked stream drainages and impounded lakes. In Japan, it has never been given a front-page coverage that total 4 billion JPY is spent annually even to this date to stabilize unstable debris mass of total 200 million $\mathrm{m}^{3}$ blocking the upper reaches of the $50 \mathrm{~km}$ long Joganji River in Tateyama Caldera; the debris mass of total 400 million $\mathrm{m}^{3}$ at that time was originated in the 1858 Hietsu Earthquake with the estimated magnitude of 7 to 7.1.

A landslide mass that blocks water and impounds a lake at its upstream is referred to as a "landslide dam". Landslide damming events are very common around the world. They pose hazards to the population at both their upstream and downstream areas because of inundations due to lake impoundment and slope stability problems associated with such impoundment, and the risk of downstream flooding, respectively. Researches on landslide dams have been focused mostly on their distribution and failure potential (e.g, Costa \& Schuster 1988, Ermini \& Casagli 2003), and less attention has been given to their emergency treatments. A retrogressive review of the emergency response and mitigation treatment for 
recent landslide damming events around the world highlights the problems and uncertainty involved in mitigating the risk from landslide dams.

The simplest and the most commonly used mitigation measure has been the excavation of a spillway which is normally constructed at the lowest point at the crest of a landslide deposit. The excavation of the spillway has been proven to be the best engineering technique for mitigating risks posed by landslide dams, and its application can be traced about 500 years back (Bonnard, 2006). Sometimes blasting is also done to help excavating the channel; however blasting is seldom done for complete removal of large landslide masses. Drainage of the dammed lakes by means of pumps and siphons is a relatively less common treatment and is limited to small lakes. Tunnels or diversion channels are also rarely adopted as mitigation measures owing to the cost and time required.

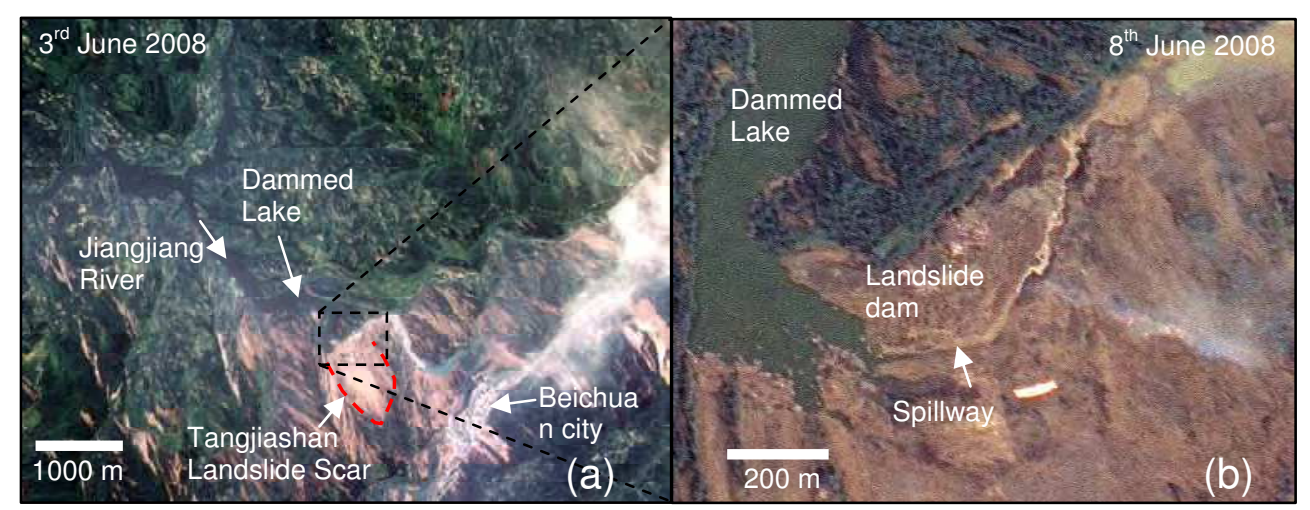

Fig. 1. True-color image of Tangjiashan landslide dam and dammed lake captured by NASA's Earth Observing-1 (EO-1) (a) on 3rd June 2008 prior to overtopping and (b) on $8^{\text {th }}$ June after overtopping but before the breaching of dam

A retrogressive review of the emergency response and mitigation strategies for recent landslide damming events around the world is presented in this chapter. Four landslide dams are presented for this purpose, consisting of the Tangjiashan landslide dam which was triggered by the 2008 Wenchuan earthquake in China, the Higashi Takezawa landslide dam that was triggered by the 2004 Mid-Nigata earthquake in Japan, the Attabad landslide that was formed in 2010 in Hunza Pakistan, and the Hattian Bala landslide dam that was formed by the 2005 Kashmir earthquake in Pakistan. A brief description of the mitigation measures adopted for the dams is given and failures of Tangjiashan landslide dam and Hattian landslide dam are also explained. A detailed description of the geomorphologic changes resulting from the Hattian landslide dam is also provided to elucidate long lasting hazards that landslide dams pose to their surrounding areas.

\section{Tangjiashan landslide dam}

The Ms 8.0 Wenchuan earthquake of China occurred on 12 May 2008 that have reportedly created 256 landslide dams most of which were formed along the Yingxiu-Beichuan (Lonmenshan) fault, which was dislocated over its $270 \mathrm{~km}$ stretch in the earthquake (Qiang at el., 2009). The Tangjiashan landslide dam (N31 $\left.50^{\prime} 39.54^{\prime \prime}, \mathrm{E} 104^{\circ} 25^{\prime} 45.93 "\right)$ is located in 
northern part of the fault zone, and impounded a lake on the Jiangjian River (Fig. 1). This lake behind the $124 \mathrm{~m}$ high landslide dam had a maximum storage capacity of 320 million $\mathrm{m}^{3}$ (Liu at el., 2010). The dam posed a great threat of flooding to the 1.2 million people living along the lower reach of the river, therefore required immediate mitigation measures.

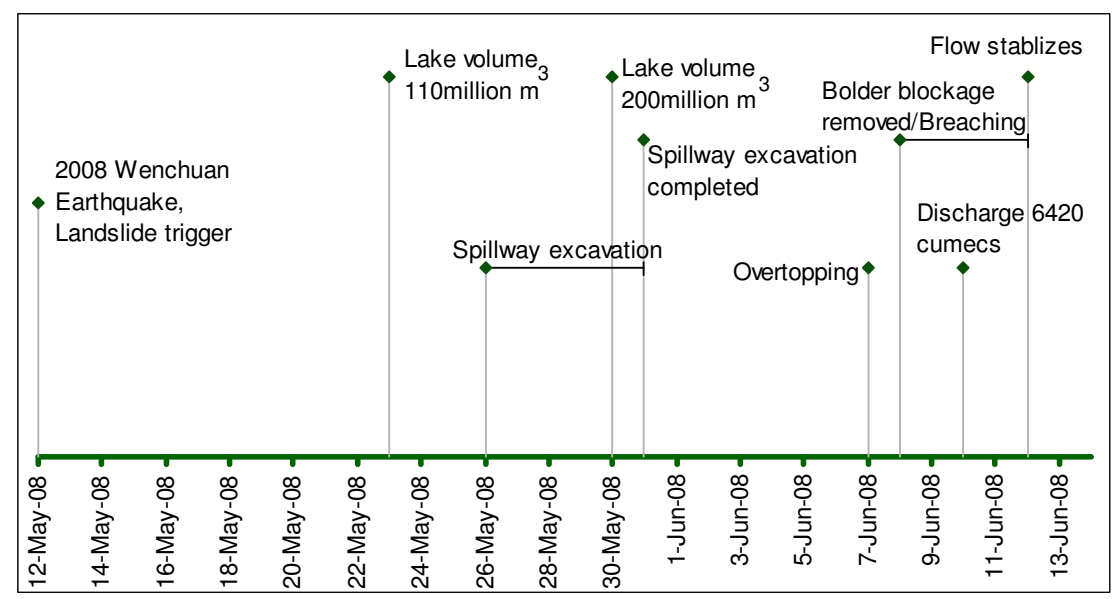

Fig. 2. Timeline of Tangiiashan landslide dam emergency response

\subsection{Emergency response and mitigation measures}

The water level of the dammed lake initially rose at a rate of $1.2 \mathrm{~m} /$ day under the average flow rate of $80-90 \mathrm{~m}^{3} / \mathrm{s}$, and later on the rate decreased to $0.5 \mathrm{~m} /$ day (Liu at el., 2010). Six towns and two cities are located downstream of the dam that were threatened to be inundated by the dam-break-caused flood. The dam break studies showed that a catastrophic flood would occur if no mitigation measures were adopted. Till $23^{\text {rd }}$ of May the

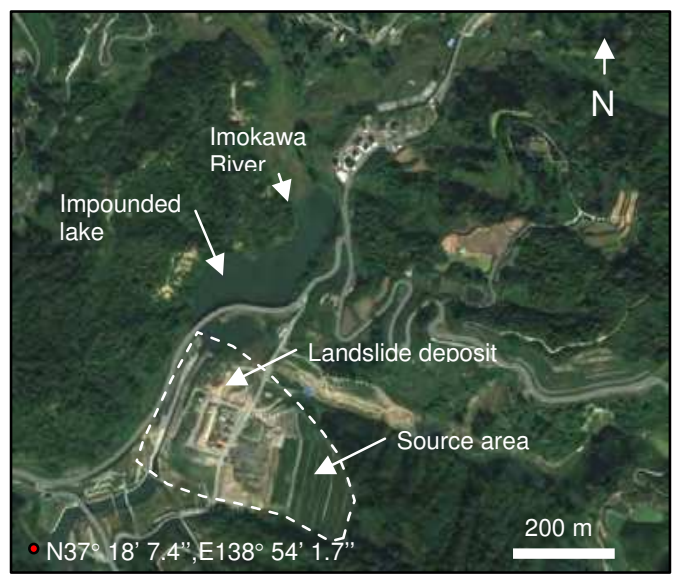

Fig. 3. Higashi Takezawa landslide dam and the dammed lake (Satellite imagery from Google Map) 
total volume of the lake had reached 110 million $\mathrm{m}^{3}$ and then 200 million $\mathrm{m}^{3}$ till the end of May, 2008. The figure 2 presents the timeline of the Tangjiashan landslide dam emergency response. The lake hypsometric curve showed that if the lake level was kept at $740.3 \mathrm{~m}$, the storage capacity of the lake would be reduced to 238 million $\mathrm{m}^{3}$ instead of 320 million $\mathrm{m}^{3}$ corresponding to the natural potential overtopping level of $755.0 \mathrm{~m}$ (Liu at el., 2010). Accordingly the civil works were carried out to excavate a spillway to minimize the potential dam breach damage. It took 7 days work from May 26 to 31, to excavate a $13 \mathrm{~m}$ deep and $8 \mathrm{~m}$ wide channel covering $475 \mathrm{~m}$ in length. The primary intension for the excavation of the spillway was to reduce the total volume of the lake and meanwhile to create a controlled flood to drain the lake. About 275,000 people evacuated from the downstream areas for the expected flood.

\subsection{Retrospective review of breaching event}

The lake level reached $740 \mathrm{~m}$, and the water started overflowing through the channel on June 7 (Qiang at el., 2009, Liu at el., 2010). The breaching process did not initiated immediately; instead the water kept rising for two days. A huge block slowed the channel erosion which was later removed by blasting on $8^{\text {th }}$ June. However, no rapid flow occurred till 10th June when the water level reached $742 \mathrm{~m}$. Then the outflow increased rapidly, and the channel walls and bed eroded rapidly. The outflow discharge peaked at $6420 \mathrm{~m}^{3} / \mathrm{s}$ on June 10, and the erosion stopped on $12^{\text {th }}$ June. Downstream areas were inundated where the people were evacuated before the breaching. The debris mass from the breached dam were transported and deposited along the downstream reaches. The emergency work for Tangiiashan landslide dam was a successful case history of response where the early identification of the hazard had made it possible to map out necessary measures for the area.

\section{Higashi Takezawa landslide dam}

The M6.8 Mid-Niigata Prefecture earthquake of 23rd October 2004 triggered numerous landslides and formed more than 50 landslide dams along the Imokawa River and its tributaries. Among these landslide dams the most crucial dam was the Higashi Takezawa
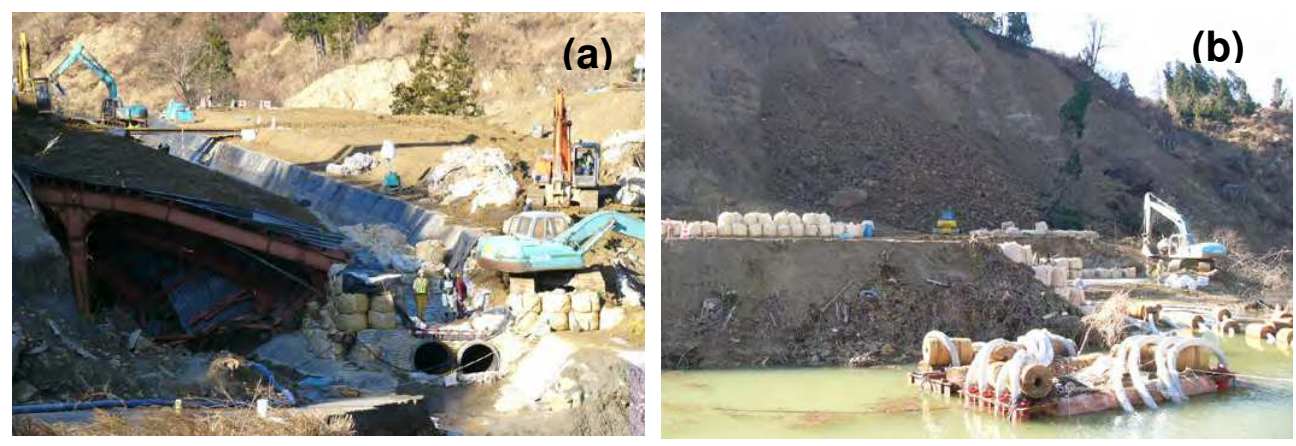

Fig. 4. Emergency works at Higashi Takezawa landsldide dam. Photo taken on 20.12.2004 by Takeji \& Tadashi, 2005 
landslide dam $\left(\mathrm{N} 37^{\circ} 18^{\prime} 16.41^{\prime \prime}, \mathrm{E} 138^{\circ} 54^{\prime} 16.13^{\prime \prime}\right)$, the largest landslide dam triggered by the earthquake (Fig. 3). The landslide originated from the left bank of the Imokawa River at Higashi Takezawa district. The landslide mass was about $350 \mathrm{~m}$ long and had volume up to 1 million $\mathrm{m}^{3}$ (Sassa, 2005). The blockage started to impound a lake and soon the water started to inundate the Kogomo village. Due to the possible danger of overtopping and successive breaching of the dam emergency measure were taken to prevent the failure.

\subsection{Emergency response and mitigation measures}

Due to the danger of possible failure of the dammed lake, it was necessary to reduce the total capacity of the lake. Two possible mitigation measures were considered to cope with the flood hazard that the landslide dam posed. One of the possible measures was to remove the blockage to the original river level to drain the lake completely. This option would favor people living both upstream and downstream reaches of Imogawa River. However, there was a concern that removing only the toe part of the landslide mass would reactivate the movement of the remaining landslide mass. Removing the entire landslide mass would not be considered as a cost-effective solution. Therefore, the landslide mass was planned to be consolidated with the combination of diversion pipes and spillway. This meant that in exchange for abandonment of the upstream Kogomo village, the relevant authorities have secured the lower reach of the dam. Inhabitants of Kogomo Village were offered alternate sites for their new dwellings.

The following steps have been taken for stabilizing the landslide mass: twelve pumps were installed first to lower and keep the lake water level $11.5 \mathrm{~m}$ below the overflow point. In addition, the outflow level was raised by $3 \mathrm{~m}$ with sand bags at the outlet. Keeping in view the pumping power for this temporary system, diversion pipes were installed in case water overtopped the landslide mass (Fig. 4). Finally, a 280m long concrete-faced spillway was constructed with its cross-section large enough for snow melts.

Closed circuit televisions (CCTV) were installed to monitor the conditions in the catchment in case of emergency. Other monitoring activities included observations of cracks, installation of the water level gauges and monitoring the surface displacement of the collapsed slope.

\section{Attabad landslide dam}

On $4^{\text {th }}$ January 2010 a landslide $\left(36^{\circ} 18^{\prime} 50^{\prime \prime} \mathrm{N}, 74^{\circ} 49^{\prime} 13^{\prime \prime} \mathrm{E}\right)$ occurred at Attabad in Hunza, Gilgit Baltistan. The debris mass dammed the Hunza river and formed a lake which was 120 $\mathrm{m}$ deep at the saddle point of the debris mass. At about $3 \mathrm{~km}$ downstream of the landslide dam, there is a site of an older landslide that blocked a $30 \mathrm{~km}$ long lake that formed in 1958 and eventually breached and caused a catastrophic flood. Prior to the 2010 Attabad landslide, cracks were being observed by the villagers at Attabad, which were being progressively lengthened. The area was declared as high hazard area by the local authorities, and evacuations of the affected slopes was being implemented by the end of 2009. 


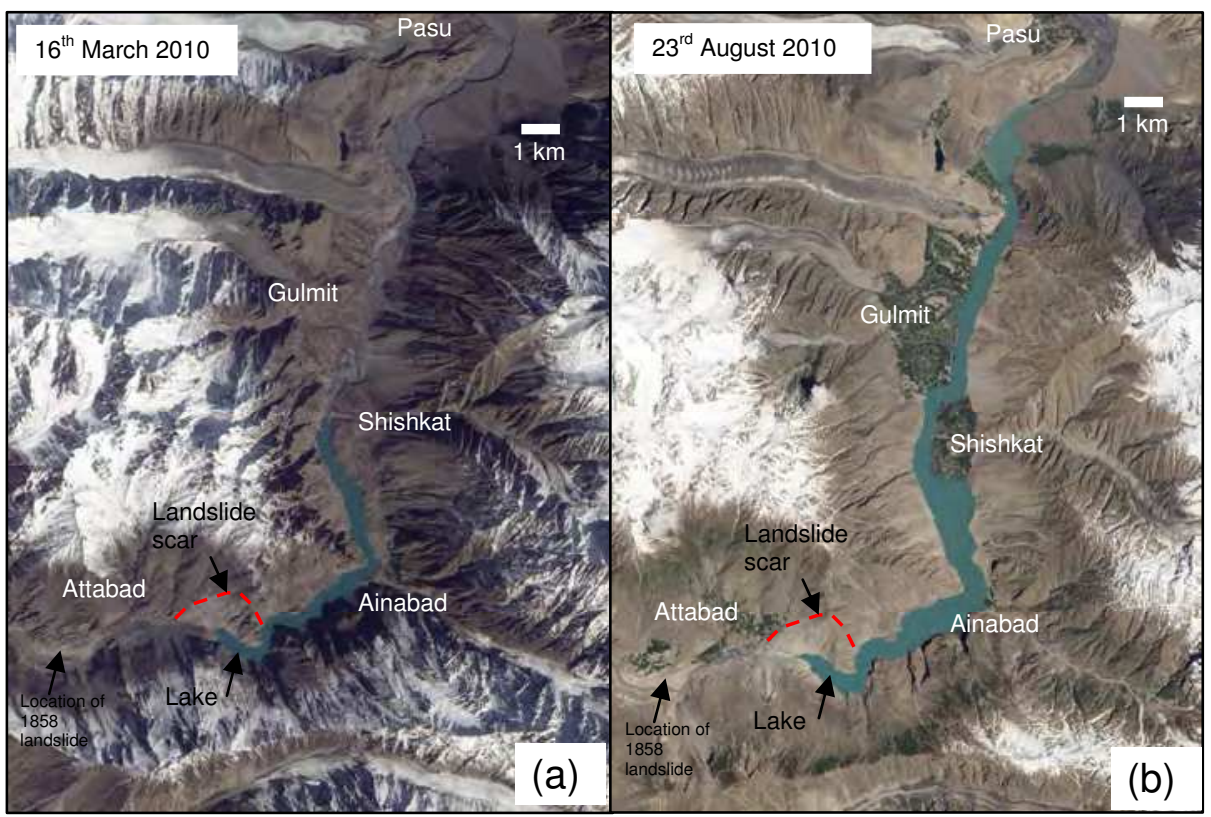

Fig. 5. The true-color image of the Attabad landslide dam $\left(36^{\circ} 18^{\prime} 50^{\prime \prime} \mathrm{N}, 74^{\circ} 49^{\prime} 13^{\prime \prime} \mathrm{E}\right)$ and lake captured by Advanced Land Imager (ALI) on NASA's Earth Observing-1 (EO-1) satellite, on (a) 16 $6^{\text {th }}$ March 2010 and (b) 23rd March 2010

\subsection{Emergency response and mitigation measures}

A lake immediately started to develop at upstream of the debris mass. The impoundment created huge problems for the 25,000 people living at upstream of the landslide dam. Mitigation studies were conducted (Petley, 2010) and as an emergency repose a $30 \mathrm{~m}$ deep spillway was planned to be excavated to reduce the maximum possible volume of the lake. Seepage points emerged progressively at six different locations till April 2010. Meanwhile, closed circuit television, (CCTV) system was installed to issue a warning in case of much feared seepage failure. The excavation of the spillway started on 30th January 2010. The surface silty-clay deposit created problems during the excavation works as the construction machinery were bogged down with the muddy conditions at the site, and the work was stopped when the excavation had reached $15 \mathrm{~m}$ deep across the crest till 16th May 2010. The water started overflowing on 29th May 2010. At the time of overtopping the lake reached a length of $21 \mathrm{~km}$ and had an estimated volume of $450 \times 10^{6} \mathrm{~m}^{3}$. Fig $5 \mathrm{a}$ and $4 \mathrm{~b}$ shows the truecolor image of the Attabad landslide dam and lake captured by Advanced Land Imager (ALI) on NASA's Earth Observing-1 (EO-1) satellite, on 16 ${ }^{\text {th }}$ March 2010 and 23rd August 2010 respectively. About 25,000 people were cut off from the downstream population and are still suffering at the moment of writing. 


\subsection{Post overtopping situation}

The Attabad landslide dam survived the much feared failure upon overtopping. The dam has emerged as a permanent geological feature that has caused a $23 \mathrm{~km}$ stretch of the Karakorum highway and about 232 houses to be inundated (NDMA) and isolated the communities at its upstream reaches. Moreover the longevity of the dam is coming under question. Erosion of the spillway occurred at the time of overtopping that continued for several days which later on was followed by a slow down-cutting of the channel. The channel erosion was stopped by the presence of large boulders embedded in the channel bed, which prevented the catastrophic failure, while slowed the drainage of the lake. The dam survived the high discharge of glacier melting of 2010. Blasting option was considered

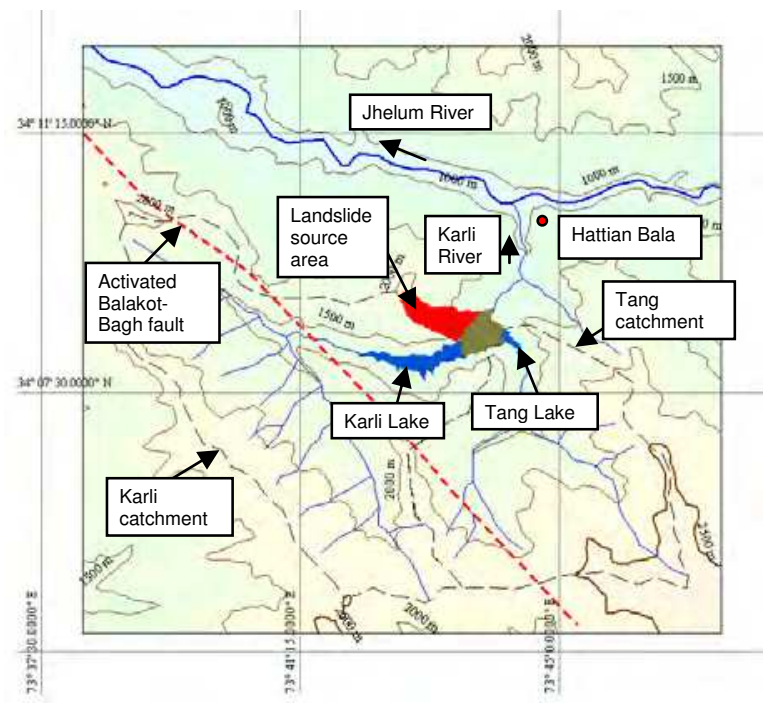

Fig. 6. Contour map of Hattian landside, dammed lakes with their catchments and downstream areas.

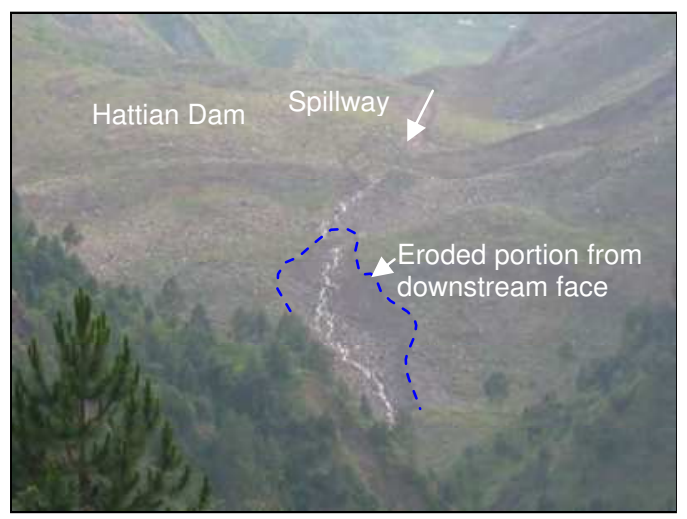

Fig. 7. Front view of the Hattian landslide mass, showing the downstream face erosion. 
to widen the spillway in late June, 2010 which was conducted at small scale and was unsuccessful (Pamir Times). As the water level of the lake dropped, attempts were made to lower the level of the spillway in January 2011, which was eventually unsuccessful.

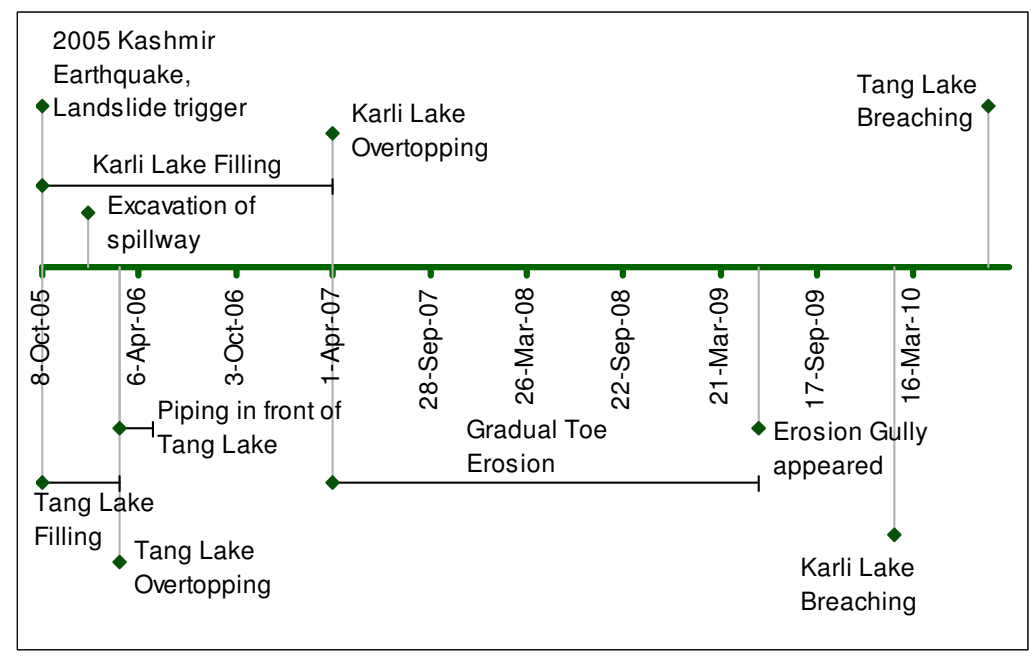

Fig. 8. Timeline of post formation features and major events at Hattian Bala landslide dam

Possible failures will include those due to down cutting erosion, seepage or piping failure, earthquake induced dam collapse, landsliding into the lake, and the glacial lake outburst flood (GLOF). The concerns are rising as the water level of the lake started increasing in June-July 2011 because of the glacier melting. The dam is intact at the moment of writing; however the stability of the dam is again threatened as the monsoon of 2011 approaches.

\section{Hattian Bala landslide dam}

On the 8th October 2005 earthquake (epicenter $34^{\circ} 29^{`} 35$ " N, $73^{\circ} 37^{\prime} 44$ " E, focal depth 26 km, 7.6 Mw (USGS)) caused widespread destruction in northern areas of Pakistan and Pakistan-administered Kashmir, killing more than 86,000 people. The earthquake triggered a large landslide mass near the south-eastern end of the Balakot-Bagh fault, the fault that caused the earthquake (Fig. 6). The slopes around the landslide source area have been a site of frequent landslide activities predating the earthquake. The 65 million $\mathrm{m}^{3}$ landslide destroyed a village and killed about 1000 people (about $1.1 \%$ of total earthquake casualties) making it one of the most devastating recorded historical landslide events (Dunning at el., 2007). The landslide blocked two tributaries of the Karli River and created two lakes, Karli Lake (large lake) with a maximum natural capacity of 86 million $\mathrm{m}^{3}$, and a Tang lake (small lake) with maximum natural capacity of 5 million $\mathrm{m}^{3}$. Immediately the water started to be impounded in the two lakes behind the landslide mass, and thus a threat of dam breach flooding was eminent. 

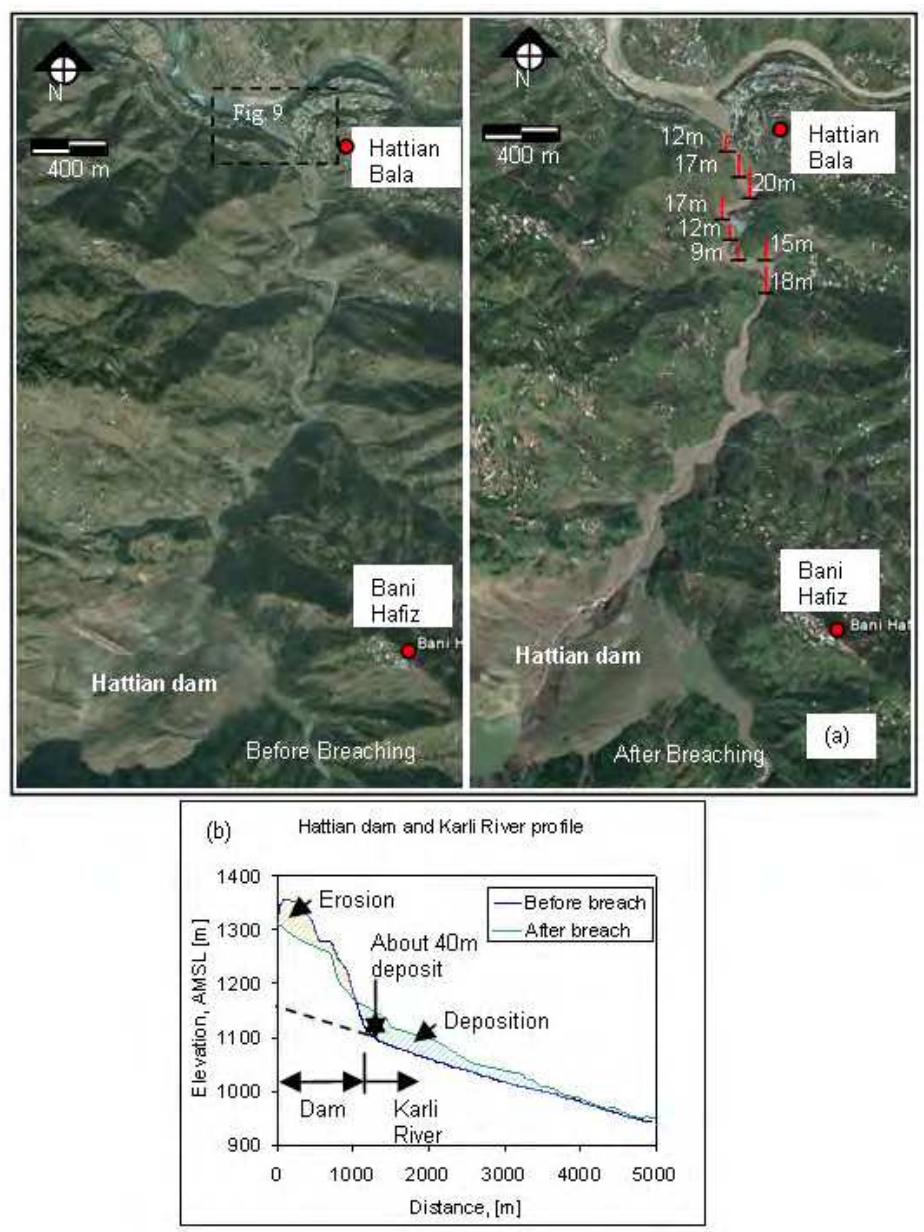

Fig. 9. (a) Satellite imageries of Karli River before and after breaching of Hattian dam (Google Earth), along with the maximum flow depths measured along the Karli River after failure of the dam (b) Profile of Hattian dam and Karli River before and after breaching of the Hattian dam

\subsection{Emergency response and mitigation measures}

As the water level in the lakes rose, the concern about the stability of the landslide dam was increasing. Mitigation studies were conducted and based on the recommendations the relevant authorities decided to excavate a spillway to reduce the maximum possible volume of the lake. The seepage through the landslide mass, the water levels and inflows to the lakes were continuously monitored as part of emergency response (WAPDA, 2007). A $450 \mathrm{~m}$ long spillway was excavated for the Karli Lake and relatively short $130 \mathrm{~m}$ spillway was excavated for the Tang Lake. The excavation of the spillway considerably reduced the total natural storage capacity of the Karli Lake from 86 million $\mathrm{m}^{3}$ to 62 
million $\mathrm{m}^{3}$. The Tang Lake filled up in February 2006 and started overflowing. A timeline of various events occurring at Hattian Bala landslide dam after its formation are presented in figure 8 .

The debris mass developed seepage erosion and the water level of the Tang Lake gradually reduced by 7-8 m over a period of two months (May-June 2006) and later on reached a state of equilibrium between inflow and seepage discharges, keeping the lake volume at approximately 3.5 million $\mathrm{m}^{3}$. The Karli Lake filled up in April, 2007 and started to overflow. The dam survived the overtopping and hence less attention was drawn towards the monitoring of the dam as the spillway was performing well and no immediate threat was imminent. On the basis of the comparison between the volumes of the debris mass with the volume of the water stored in the lake the dam was thought to be stable by many experts. Therefore, less attention was drawn towards the monitoring of the dam site. However, after overtopping gradual erosion of the dam body started to occur due to the overflowing and seepage water.

\subsection{Breaching and breach inflected morphological changes}

Gradual toe erosion was initially observed, which was then followed by a rapid head cutting erosion of the downstream face of the dam (Fig. 7). On 9th February 2010, the water of Karli Lake breached the debris dam after five days of incessant rain, and the breaching drained about 36 million $\mathrm{m}^{3}$ of water from the lake. According to the back analysis conducted by Konagai, at el., (2011) the peak outflow was about $5500 \mathrm{~m}^{3} / \mathrm{s}$. A moderate $32 \mathrm{~mm} /$ day rainfall was estimated on the day prior to the day of breaching. About 7.78 million $\mathrm{m}^{3}$ of soil was estimated to have been eroded during the breaching event. The flushed debris mass was deposited along the Karli River. Fig. 9 shows the satellite image and profile of the Karli River before and after the breaching. A major portion of the eroded material is deposited over the approximately $2 \mathrm{~km}$ downstream stretch from the dam along Karli River and less significantly beyond the stretch. The flow along the Karli River reached the depth up to $20 \mathrm{~m}$. The debris deposit was about $40 \mathrm{~m}$ thick near the toe of the dam.

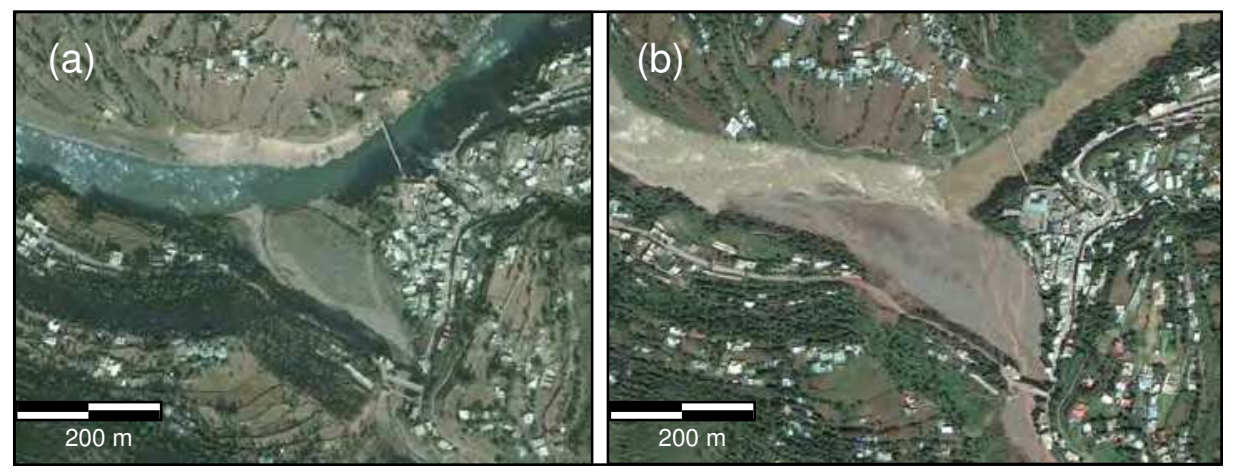

Fig. 10. (a) Satellite image of the junction of the Karli River with the Jhelum River before and after the breaching of Hattian dam (Google earth) 
The dam break flood and debris destroyed one bridge near the junction of the Karli River with the Jhelum River and damaged about 24 houses as shown in Fig. 10. However major damage from the dam breach occurred as a landslide on the right bank of the Karli lake that was triggered by emptying of lake water. The figure 11 shows the satellite image of the right bank landslide after the breaching event, along with the contour map of the landslide and longitudinal profile of the landslide. This landslide destroyed 174 houses forcing about 1000 residents to evacuate.

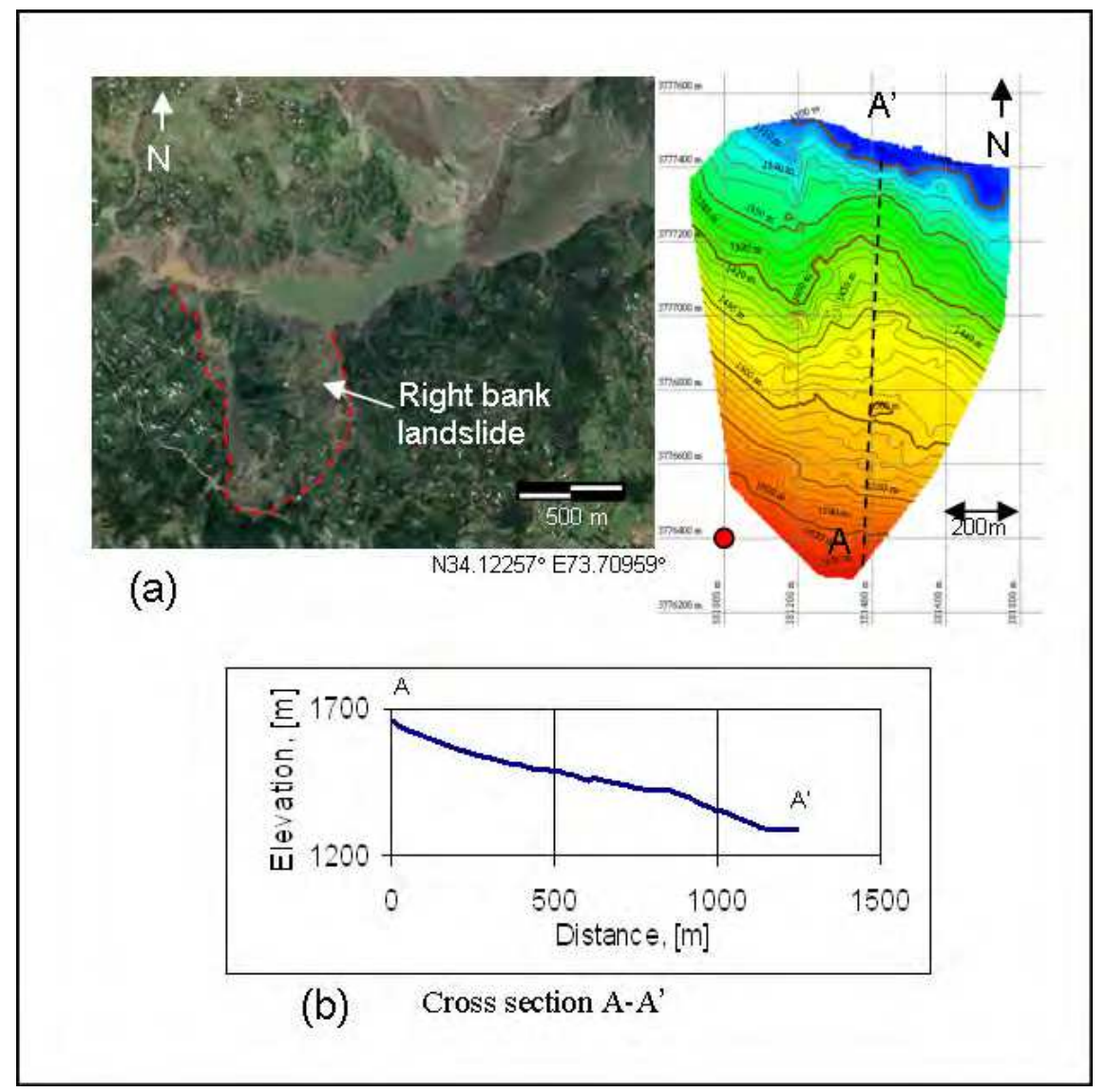

Fig. 11. (a) Satellite image of the Hattian landslide dam, Karli lake and the right bank landslide after the breaching event, along with the contour map of the landslide, (b) the longitudinal profile of the right bank slide. Modified from Konagai at el., 2011

The Tang Lake breached during the monsoon rains (July-August) of 2010. In the breaching process, the water from Tang Lake eroded the north-eastern end of the landslide lobe, which had been covered with boulders segregated up at the time of deposit, and approximately $15 \mathrm{~m}$ depth of the lake water was drained leaving 1.9 million $\mathrm{m}^{3}$ water in the lake (Fig. 12). 


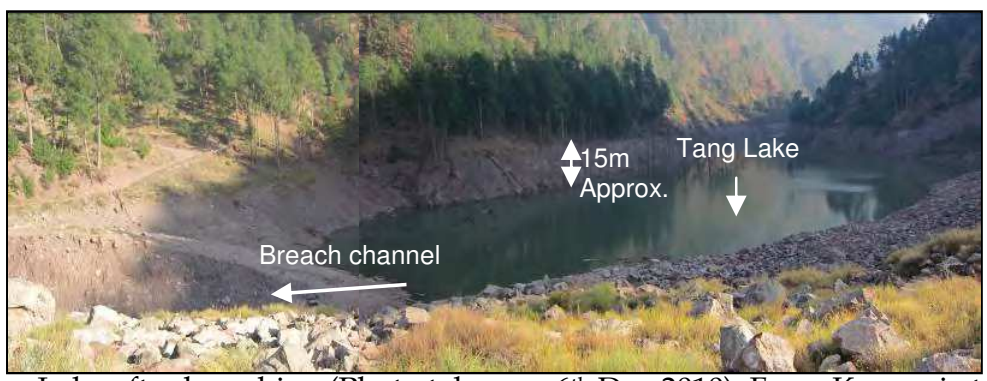

Fig. 12. Tang Lake after breaching (Photo taken on 6 th $^{\text {th }}$ Dec-2010). From Konagai at el., 2011

\section{Conclusion}

A review of emergency responses and mitigation strategies adopted for the landslide dams formed in the recent earthquakes shows the problems being faced in the risk management of the hazards posed by the landslide dams. Excavation of the spillway seems to be the most common and effective mitigation measure. Meanwhile the time seems to be the most crucial factor during the emergency response, as the rise of water level inundates more area at its upstream and increase the lake volume. Higashi Takezawa landslide dam presented an example where a combination of different mitigation techniques such as pumps, siphons, diversion channels, and spillway, were possible for the relatively small landslide mass which was easily accessible. For the large landslide masses at remote locations, spillway remains as the most suitable mitigation measure.

It is also observed that the failure potential of landslide dammed lakes is not a well understood phenomenon. The Attabad landslide dam which was expected to fail upon overtopping due to the material composition of the dam body survived and continues to pose threats. On the other hand the Hattian landslide dam that seemed to be relatively stable and expected to remain intact, after showing some signs of instability failed as a result of moderate rainfall. The risk assessment for landslide dam mostly considers the expected inundation from dam breach, which might not be sufficient. From the case study of Hattian landslide it is observed that the damage resulting from the slope instability as a result of drawdown can be equally severe as the damage resulting from dam breach flood.

The available response time varies from case to case, as in the case of Hattian dam it took over one year for the lake to fill, while Tangiiashan landslide dammed lake provided less then a month for the response before the lake filled. The consideration of the recent landslide dams and their emergency treatment leads to the conclusion that for potentially large landslide dams, the early identification of possible situation is essential to organize appropriate preventive actions in due time. A detailed knowledge of the past events like those mentioned above will always be helpful determining the optimum actions to be adopted considering the fact that the significant bases in this field are lacking.

\section{Acknowledgment}

This paper summarizes one of the outcomes of the MEXT Research Project, "Scientific surveys for long-lasting geotechnical problems caused by large earthquakes and their 
implementations for rational rehabilitation strategies", Konagai K. Leader of the project, 2008 Grant-in-aid for scientific research (A) No. 20254003, Ministry of Education, Culture, Sports, Science and Technology (MEXT).

\section{References}

Bonnard C. (2006). Technical and Human aspects of historic rockslide dammed lakes and landslide dam breaches, Italian journal of engineering geology and environment, Special issue 1 doi: 10.4408/IJEGE.2006-01.S-03

Costa J. E. and Schuster R. L. (1988). The formation and failure of natural dams, GSA Bulletin; July 1988; v. 100; no. 7; p. 1054-1068; DOI: 10.1130/00167606(1988)100<1054:TFAFON>2.3.CO;2

Dunning S. A., Mitchell W. A., Rosser N. J., Petley D. N. (2007). The Hattian Bala rock avalanche and associated landslides triggered by the Kashmir Earthquake of 8th October 2005, Eng Geol 93(3-4):130-144

Ermini L., Casagli N. (2003). Prediction of the behaviour of landslide dams using a geomorphological dimensionless index, Earth Surface Processes and Landforms, Volume 28, Issue 1, pages 31-47, January 2003 DOI: 10.1002/esp.424

Geological Survey of Pakistan (GPS). (2010). Post disaster threats in Attabad and adjacent areas, Hunza valley, Gilgit-Baltistan, Information release no 893, April 2010

Konagai K., Ahsan S. (2011). Partial breaching of Hattian Bala landslide dam formed in the 8th October 2005 Kashmir earthquake, Pakistan, Landslides Journal (in review)

Liu N., Chen Z., Zhang J., Lin W., Chen W. and Xu W. (2010). Draining the Tangjiashan Barrier Lake, DOI: 10.1061/ ASCE 7 HY.1943-7900.0000241, Journal of Hydraulic Engineering, Vol. 136, No. 11, November 1, 2010

Pamir Times. Voices of the Mountain Communities, community news and views blog of Gilgit - Baltistan. http://pamirtimes.net/

Petley D. (2010). The landslide at Attabad in Hunza, Gilgit/Baltistan: current situation and hazard management needs. Report prepared for Focus Humanitarian Assistance, Pakistan, based upon a rapid field assessment on 26th February - 4th March 2010

Qiang X., Xuan-Mei F., Run-Qiu H., Cee V. (2009). Westen Landslide dams triggered by the Wenchuan Earthquake, Sichuan Province, south west China. Bull Eng Geol Environ (2009) 68:373-386 DOI 10.1007/s10064-009-0214-1

Randall W. Jibson and Edwin L. Harp (2011). Field Reconnaissance Report of Landslides Triggered by the January 12, 2010, Haiti Earthquake Open-File Report 2011-102 U.S. Department of the Interior U.S. Geological Survey

Sassa K. (2005). Landslide disasters triggered by the 2004 Mid-Niigata Prefecture earthquake in Japan Landslides, (2005) 2: 135-142. DOI: 10.1007/s10346-005-0054-4

Takeji Kokusho and Tadashi Hara (2005): Photographs of Landslides triggered in the 2004 Chuets Earthquake, Earthquake damage in active-folding areas: Creation of a comprehensive data archive and suggestions for its application to remedial measures for civil-infrastructure systems (Project leader: Kazuo Konagai), Research and Development program for Resolving Critical Issues, Special Coordination Funds for Promoting Science and Technology, Ministry of Education, Culture, Sports, Science and Technology, 2005-2007. 

Soil Liquefaction and Seismic Safety of Dams and Monuments

WAPDA Report. (2007). Study of Hattian Ballah landslide, Potential hazards of land sliding and mitigation measures at Hattian Ballah and other earthquake hit areas, National Engineering Services Pakistan limited (NESPAK) and Geological Survey of Pakistan (GSP), Water and Power Development Authority (WAPDA), 2007, Government of Pakistan 


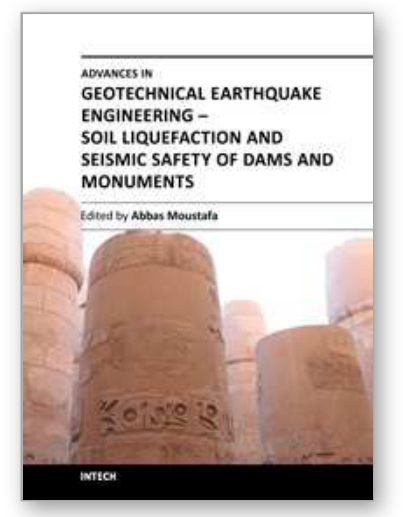

\author{
Advances in Geotechnical Earthquake Engineering - Soil \\ Liquefaction and Seismic Safety of Dams and Monuments \\ Edited by Prof. Abbas Moustafa
}

ISBN 978-953-51-0025-6

Hard cover, 424 pages

Publisher InTech

Published online 10, February, 2012

Published in print edition February, 2012

This book sheds lights on recent advances in Geotechnical Earthquake Engineering with special emphasis on soil liquefaction, soil-structure interaction, seismic safety of dams and underground monuments, mitigation strategies against landslide and fire whirlwind resulting from earthquakes and vibration of a layered rotating plant and Bryan's effect. The book contains sixteen chapters covering several interesting research topics written by researchers and experts from several countries. The research reported in this book is useful to graduate students and researchers working in the fields of structural and earthquake engineering. The book will also be of considerable help to civil engineers working on construction and repair of engineering structures, such as buildings, roads, dams and monuments.

\title{
How to reference
}

In order to correctly reference this scholarly work, feel free to copy and paste the following:

Ahsan Sattar and Kazuo Konagai (2012). Recent Landslide Damming Events and Their Hazard Mitigation Strategies, Advances in Geotechnical Earthquake Engineering - Soil Liquefaction and Seismic Safety of Dams and Monuments, Prof. Abbas Moustafa (Ed.), ISBN: 978-953-51-0025-6, InTech, Available from: http://www.intechopen.com/books/advances-in-geotechnical-earthquake-engineering-soil-liquefaction-andseismic-safety-of-dams-and-monuments/recent-landslide-damming-events-and-their-hazard-mitigationstrategies

\section{INTECH}

open science | open minds

\section{InTech Europe}

University Campus STeP Ri

Slavka Krautzeka 83/A

51000 Rijeka, Croatia

Phone: +385 (51) 770447

Fax: +385 (51) 686166

www.intechopen.com

\section{InTech China}

Unit 405, Office Block, Hotel Equatorial Shanghai

No.65, Yan An Road (West), Shanghai, 200040, China

中国上海市延安西路65号上海国际贵都大饭店办公楼 405 单元

Phone: +86-21-62489820

Fax: $+86-21-62489821$ 
(C) 2012 The Author(s). Licensee IntechOpen. This is an open access article distributed under the terms of the Creative Commons Attribution 3.0 License, which permits unrestricted use, distribution, and reproduction in any medium, provided the original work is properly cited. 